\title{
The Genre Debate and Satire
}

The Hebrew Bible presents contrasting depictions of King David. Chronicles is an unmistakeably favourable account of David's Kingship, ${ }^{1}$ whereas the narrative in the latter half of the Book of Second Samuel leading into the Book of First Kings presents a very different picture of David. In this account of David's reign David's character is explored in more depth, particularly in reference to his transgressions. For example, David is portrayed as having an adulterous affair with Bathsheba (2 Sam. 11:4), which he tries to conceal by having Uriah, Bathsheba's husband, executed (2 Sam. 11:14-15). Contrary to the favourable account in Chronicles, David is criticised explicitly in this narrative for these transgressions. The narrator writes that God is displeased with David (2 Sam. 11:27b), Nathan gives God's adverse judgement (2 Sam. 12:7-12), and David himself confesses that he has sinned against God (2 Sam. 12:13). Yet, the rest of the narrative that is commonly referred to as the Succession Narrative (SN) is less explicit. There are instances of apparent criticism, such as the contrast between David and Uriah in 2 Samuel 11:8-13. There are also verses which merely imply that David's behaviour is unacceptable, such as 2 Samuel 11:1. However, overall it would appear that the SN shows David in a negative light.

With the seemingly unflattering presentation of David in the passage 2 Samuel 9-20; 1 Kings 1-2, ${ }^{2}$ it is no surprise that the genre of this body of work has been debated extensively. Some of the various genre categories to which the SN has been argued to belong are, national epic, propaganda, wisdom literature, theological 'history' writing, literary art, and njals saga. Furthermore, the nature of David's character has been a subject of debate within the genre argument. Surprisingly, the varying interpretations of David's character range from those that are ultimately complimentary despite David's sins, those that are neutral with respect to his character and interpretations that are highly critical of David's behaviour.

1 McKenzie writes that the author of Chronicles was most likely a priest who was interested in documenting the building of the Temple, and the development of the institutions which were associated with the Temple. McKenzie argues that the author of Chronicles did not document David's transgressions, as they were not the focus of his writing, and to do so would tarnish the reputation of the Temple. Steven McKenzie, King David. A Biography (Oxford: Oxford University Press, 200o), 36.

2 This narrative is usually called the Succession Narrative. 
The following section discusses the different competing views of the genre of the SN, and the varied conceptions of King David and his family within these different genre categorisations of the SN. In section 1.2 I argue that the genre of the $\mathrm{SN}$ is satire and that the narrative is pejoratively critical of David.

The argument for the existence of a unified narrative beginning in the Second Book of Samuel through to the beginning of the First Book of Kings has a long history. As early as 1878 Wellhausen proposed that the narrative 2 Samuel 9-2 Kings $2^{3}$ was a single body of work which documented Solomon's colourful rise to the throne.

Leonhard Rost's dissertation of 1926, The Succession to the Throne of David, builds on this theory. Rost argues that the passage 2 Samuel 9-1 Kings 1-2 is a single authored narrative, by proposing that it is part of a self-contained unit which also includes the Ark Narrative (1 Sam. 4:1b-18a, 19-21; 5:1-11ba, 12; 6:1ba, 4, 10-14, 16; 6:19-7:1; 2 Sam. 6:1-15), and the Prophecy of Nathan (2 Sam. $7: 1-7,11 b, 16 ; 18-21,25,(26), 27-29) .{ }^{4}$ Rost's major contribution to scholarship proved to be his detailed analysis of the content and style of the passage 2 Samuel 9-20; 1 Kings 1-2, which he called the "Succession Narrative." Rost suggests that there is a uniform structure which links the narrative throughout 2 Samuel 9-20; 1 Kings $1-2 .{ }^{5}$ Rost argues that by and large the content and style of the text are consistent throughout the narrative suggesting the unity of the source. ${ }^{6}$ However, he also argues that the material on the Ammonite war (2 Sam. 10:6-11:1; 12:26-31) is from a separate source.

Both Wellhausen ${ }^{7}$ and Rost see the focus of the content in this narrative as the succession to the throne of King David. ${ }^{8}$ However, Rost maintains that it is the content which establishes the boundaries of the narrative. He argues that the material in 1 Kings 1-2 provides the conclusion to Solomon's accession to the throne, 2 Samuel 10-12 provides Solomon's background story, and

3 In Prolegomena to the History of Ancient Israel Wellhausen writes that the end of this narrative is 2 Kings $2(262)$. However, it would appear that this is a typographical error given that it is not consistent with the context of Wellhausen's discussion. I have come to this conclusion in consultation with Dr. Suzanne Boorer.

4 Rost, The Succession to the Throne of David, 84.

5 Ibid., 67.

6 Ibid., 68.

7 Wellhausen, Prolegomena to the History of Ancient Israel, 262.

8 Rost, The Succession to the Throne of David, 84. 
2 Samuel 9:13:1-20:22 gives the background story of the succession. ${ }^{9}$ Rost also suggests that theological consistency is found in the SN by the representation of Yahweh as the guardian of the moral law who requires submission from human beings, and who expresses himself indirectly in worldly events. ${ }^{10}$

The other emphasis of Rost's dissertation is the identification of unity in the text through a consistency of style. He criticizes previous research which identified the unity of texts based only on consistency of vocabulary and thoughtcontent. Rost suggests that these findings are open to debate; as shared vocabulary and shared thoughts might be found in groups of people within the same sphere of influence, and thereby, consistency may not point to a work being written by a single author. ${ }^{11}$ Instead, Rost proposes that although different writers may use the same traditional or learned literary conventions, style is highly idiosyncratic and creative. Rost writes that a single style can be determined by concise vs. expansive writing, a particular use of speech in a narrative, and the way an author chooses to tell a lengthy story (in a seamless block or as smaller stories which are rounded off within a larger narrative)..$^{2}$ Rost highlights the difference in style in the work of the Ark Narrative (1 Sam. 4:1b18a, 19-21; 5:1-11ba, 12; 6:1ba, 4, 10-14, 16; 6:19-7:1; 2 Sam. 6:1-15) the Prophecy of Nathan (2 Sam. 7:1-7, 11b, 16; 18-21, 25, (26), 27-29), the Ammonite Wars (2 Sam. 10:6-11:1; 12:26-31), and the remaining narrative in 2 Samuel 9-20; 1 Kings 1-2, to suggest how these works were authored by different people.

Although Rost does not write in detail about the genre of the text he claims that the SN was written by a member of the royal court, ${ }^{13}$ and is a highly stylized account of history. ${ }^{14}$ At this stage in the discussion scholars generally agree that the narrative 2 Samuel 9-20; 1 Kings 1-2 is a single authored work which was written in order to record the details of Solomon's rise to the throne. However, scholars were yet to strictly define genre. As mentioned, Wellhausen suggests that the style of writing in 2 Samuel 9-20; 1 Kings 1-2 is different from other biblical passages which contain fanciful representations of events and is more inclined to 'historical writing.' On the other hand, while Luther,,

9 Ibid.

$10 \quad$ Ibid., 108.

11 Ibid., 3 .

12 Ibid., 4.

13 Ibid., 105 .

14 Ibid., 104.

15 Bernhard Luther, "The Novella of Judah and Tamar and Other Israelite Novellas," In Narrative and Novella in Samuel. Studies by Hugo Gressmann and Other Scholars 19061923, edited by David M. Gunn, translated by David E. Orton, 177-206. Sheffield: The Almond Press, 1991. German original, "Die Novelle von Juda und Tamar und andere 
Caspari, ${ }^{16}$ Gressmann ${ }^{17}$ and Schulz ${ }^{18}$ all agree that the material in the books of Second Samuel and First Kings contains historical information, nevertheless they interpret the genre of this narrative as having more in common with novelistic writing. Rost's detailed literary analysis of the SN does not firmly indicate a particular genre.

After the early history of scholarship into the material in the SN, scholars began to make clearer suggestions regarding the genre of the narrative, or spoke of a distinct focus in the narrative which implied a particular genre. In these studies the categories of genre can loosely be grouped under the following headings; National Epic, Political Propaganda, Wisdom Writing, Theological 'History' Writing, Literary Art, and Njals Saga. Each of these descriptive headings considered on its own is imprecise as it is generally considered that the SN is based on actual historical events, has a theological function, and shows evidence of literary artistry. That is, the SN has key features of multiple genres and, as such, manifests genre overlap. However, consistent with this overlap of genre, it can reasonably be argued that the SN has a dominant focus, and therefore, is a better exemplar of one of these genres than of others.

In the 1940's and 1950's a clear statement and analysis of the genre of SN was yet to emerge. However, a group of scholars wrote succinctly of the narrative 2 Samuel 9-20; 1 Kings 1-2 as a national epic. ${ }^{19}$ This interpretation extended the view of the SN as 'history writing' but emphasized the author's intention

israelitische Novellen." In Eduard Meyer, Die Israeliten und ihre Nachbarstämme. Halle: Max Niemeyer, 1906.

16 Wilhelm Caspari, "The Literary Type and Historical Value of 2 Sam 15-20." In Narrative and Novella in Samuel. Studies by Hugo Gressmann and Other Scholars 1906-1923, edited by David M. Gunn, translated by David E. Orton, 59-88. Sheffield: The Almond Press, 1991. German original, "Literarische Art und Historischer Wert von 2 Sam. 15-20." In Theologische Studien und Kritiken 82 (1906) 317-348.

17 Hugo Gressmann, "The Oldest History Writing in Israel." In Narrative and Novella in Samuel. Studies by Hugo Gressmann and Other Scholars 1906-1923, edited by David M. Gunn, translated by David E. Orton, 9-32. Sheffield: The Almond Press, 1991. Original date of publication 1910.

18 Alfons Schulz, "Narrative Art in the Books of Samuel." In Narrative Art and Novella in Sam. Studies by Hugo Gressmann and Other Scholars 1906-1923, edited by David M. Gunn, translated by David E. Orton, 120-121. Sheffield: The Almond Press, 1991. Original date of publication 1923 .

19 Scholars of note include; Edmond Jacob, Histoire et historiens dans l'ancien testament (Paris: Delachaux \& Niestlé, 1957), 29; William McKane, I \& II Samuel: Introduction and Commentary (London: scm Press, 1963), 19 and Christopher R. North, The Old Testament Interpretation of History (London: The Epworth Press, 1953), 34. Robert H. Pfeiffer, Introduction to the Old Testament (London: Adam and Charles Black Limited, 1952), $35^{8}$. 
to document the great achievements of the community. Pfeiffer suggests that the author's only bias is his pride in the nation's achievements. ${ }^{20}$

A decade later a body of scholars began to speak of the SN as a work of political propaganda. Timothy Thornton argues that it was necessary for Solomon to justify his rise to the throne, given that he was not the first in line to be king, and because there were a number of controversial executions at the start of Solomon's reign, including Adonijah, Joab, and Shimei. ${ }^{21}$ Harry Hoffner also argues that the $\mathrm{SN}$ is a work of political propaganda. ${ }^{22}$ Kyle McCarter builds on Hoffner's work when he claims that 1 Kings 1-2 is a court apology for Solomon and David. ${ }^{23}$ He suggests that questions of Solomon's legitimacy to take the throne must have circulated in the community at the time, and as a result, 1 Kings 1-2 (which vindicated Solomon) was written. ${ }^{24}$ Keith Whitelam suggests that the depiction of David in the stories known as David's rise and the narrative in the SN is a work of royal propaganda. Whitelam argues that it was necessary to manipulate the story of David in order to show that his kingdom was stable, to protect it from threats, and to justify his usurpation of Saul's throne. ${ }^{25}$

Whybray suggests that the $\mathrm{SN}^{26}$ was written at a time of 'enlightenment' when Israel was influenced by the wisdom tradition of its neighbours, ${ }^{27}$ and when foreign scribes would have taught at similar schools in Israel. ${ }^{28}$ Such a proposition then leads Whybray to conclude that the author of the SN chose to use a historical subject in order to teach the students wisdom, about the reallife situation that they would find themselves working within. ${ }^{29}$

$20 \quad$ Ibid.

21 Timothy C. G. Thornton, "Solomonic apologetic in Samuel and Kings," cQR, 169 [371] (1968), 159-166, 161.

"Propaganda and Political Justification in Hittite Historiography," in, H. Goedicke and J. J. M. Roberts, eds., Unity and Diversity Essays in the History Literature, and Religion of the Ancient Near East (London: John Hopkins, 1975), 49-62 as cited in, P. Kyle McCarter Jr., "Plots, True and False." The Succession Narrative as Court Apology," Int 354 (1981), $355-367,358$.

23 McCarter Jr., "Plots, True or False." The Succession Narrative as Court Apology," 357.

24 Ibid., 360.

25 Keith W. Whitelam, "The Defence of David," Jsот, 29 (1984), 61-87, 62.

26 Whybray generally agrees that the narrative from 2 Samuel 9-20; 1 Kings $1-2$ is a single authored body of work. However, he suggests that 2 Samuel 10:1-11:1a and 12:26-31 are separate war annals; 2 Samuel 12:7b-10, 11f, 13b-14 are repetitious and therefore suspicious, and that 1 Kings $2 \mathrm{~b}: 4$, and 27 are not original. Ibid., 8-9.

27 Whybray, The Succession Narrative. A Study of II Sam. 9-20 and I Kgs 1 and 2, 1 \& 7 .

28 Ibid., 56 .

29 Ibid., 8o. 
In the 1940's Von Rad suggests that the genre, of what would later be called the SN, was a kind of theological history writing. ${ }^{30}$ In the 1970's Walter Brueggemann also suggests that the genre of the $\mathrm{SN}$ is historical/theological writing. In particular he maintains that the theme of succession in 2 Samuel 9-20; 1 Kings $1-2$ is theologically significant as it emphasises the working out of Yahweh's promise to David, and Israel. ${ }^{31}$

Contrary to this, Otto Eissfeldt favours the view that the SN is literary art. He argues that the SN outlines historical events, but does so in a way that is artistically crafted. ${ }^{32} \mathrm{He}$ proposes that the SN cannot be called history writing, as it does not document events as annals might, but rather presents events in a deliberate manner with much fictitious ornamentation. ${ }^{33}$ Gunn builds on these ideas by suggesting that the material in the $\mathrm{SN}$ is primarily a work of art and an entertaining story. ${ }^{34} \mathrm{He}$ argues that this story is traditional in nature, drawing on motifs found in the OT and in other literature. Furthermore, Gunn argues that all of these motifs have a literary purpose. He suggests that these traditional motifs may have some basis in historical fact, but that the narrative neglects historical reporting in favour of creating an entertaining story. ${ }^{35}$

Gunn also suggests that there are passages within the SN that have improbable 'historical' similarities, including; 2 Samuel 16:1 and 1 Samuel 15:18, where the gifts of food are striking, ${ }^{36}$ and 2 Samuel 18:6-7, which has similarities to other stories in Samuel. ${ }^{37}$ The implication is then, that these stories are literary fiction. Gunn therefore, concludes that this work finds its origins both in history and the oral tradition of story-telling - a tradition that used these literary patterns to provide artistic flair to the material. The highly crafted nature of

30 Gerhard von Rad, "The Beginnings of Historical Writing in Ancient Israel," in From Genesis to Chronicles. Explorations in Old Testament Theology (Minneapolis: Fortress Press, 2005), 125-126. German original, Von Rad 'Der Anfang der Geschichtssccherib ung im alten Israel' Archiv für Kulturgeschichte, 32 (1944), 1-42.

31 Walter Brueggemann, "On Trust and Freedom: A Study of Faith in the Succession Narrative," Int, 26 (1972), 3-19, 4.

32 Otto Eissfeldt, The Old Testament. An Introduction (Oxford: Basil Blackwell, 1966), 143.

33 Ibid., 48.

34 Gunn, The Story of King David. Genre and Interpretation, 13. Although Gunn does use the term 'Succession Narrative,' it is worth noting that he does not believe that Solomon's ascension is the primary focus of this narrative; indeed, Gunn writes that Solomon is scarcely mentioned in the narrative. Instead Gunn views this as a narrative, where David is the protagonist of the story. 82 .

35 Ibid., 49 .

36 Ibid., 50 .

37 Ibid., 51. 
the narrative and the important story encourages Gunn to call the narrative serious entertainment. ${ }^{38}$

Van Seters makes the argument that the material in the SN (or what he calls the David Saga $)^{39}$ is akin to Njals sagas, which are a particular form of Icelandic family sagas ${ }^{40} \mathrm{He}$ maintains that these sagas are a fictitious account of history. ${ }^{41}$ Yet, Van Seters also suggests that these sagas go towards creating a national identity, albeit a 'truer' account of history, which subverts or satirizes the corruptions of the past. ${ }^{42}$

Van Seters prefers the title David Saga as he suggests that the theme of succession is a sub-theme within a wider narrative which presents David's entire public life, beginning with his rise to power, and only ending with a new king rising to the throne. ${ }^{43}$ David's Saga, Van Seters suggests, is a parody of an earlier Deuteronomistic document, which was a favourable account of David's reign. ${ }^{44}$

Furthermore, Van Seters suggests that the Deuteronomistic History of David, which presents David as a just and righteous king, is subverted in the David Saga, where David is shown to be anything but a model ruler. ${ }^{45}$ Instead, he argues that David is shown to be congruent with the worst Kings in Israel's history including; Ahab, Jeroboam, and Saul. ${ }^{46}$ Consequently, Yahweh makes a judgement over the entire Davidic dynasty. ${ }^{47}$ Van Seters argues that the David Saga parodies the divine promise of the everlasting Davidic kingship, because it portrays David as a king who took the throne. ${ }^{48} \mathrm{He}$ then suggests that the over-arching question that arises in this text is: "Is this what you really want?"49 This question, Van Seters interprets as anti-monarchical and anti-messianic.

\footnotetext{
$38 \quad$ Ibid., 61.

39 Van Seters does not speak of the SN but rather the David Saga. In terms of the boundaries of this work, he includes the boundaries of Rost's thesis, but also adds 2 Samuel 2:84:12, and 2 Samuel 1:5-10 and 13-16. Furthermore, Van Seters uses the designation "Court History" instead of SN as Van Seters believes that there is less of a focus on the theme of succession than Rost claims. John Van Seters, The Biblical Saga of King David (Indiana: Eisenbrauns, 2009).

$40 \quad$ Ibid., 42.

41 Ibid., 42.

42 Ibid., 354-355.

43 Van Seters, The Biblical Saga of King David, 331.

44 Ibid., 2.

45 Ibid., 291.

46 Ibid., 343.

47 Ibid., 299 .

48 Ibid., 357 .

49 Ibid., 358.
} 
I claim that the genre of the $\mathrm{SN}$ is a satire (in addition to being an historical account with a theological function). This line of research has emerged from two different lines of inquiry. In the first instance, I have been influenced by the body of research which considers the SN to be a work of literary art. The second line of inquiry has been my own research into irony in the SN. In terms of the first line of inquiry, I am most interested in Van Seters' research that has built on Gunn's claim that the SN is serious entertainment. Furthermore, Van Seters' suggestion that the 'David Saga' is a parodying work that subverts earlier ideas, themes and traditions ${ }^{50}$ seems to align well with the suggestion that the $\mathrm{SN}$ is a satire. This suggestion is particularly evident in Van Seters' remark,

... there is a stratum within the story of David that reflects an attempt to 'demythologize the tradition' that is similar to what is evident in the Njals saga. This stratum, which is reflected in the so-called Court History, presents a complete subversion of the older idealized David in DtrH and a parody of many of its major themes, and it does so by means of the same artistic qualities of character portrayal and 'realistic' recreation of the past that one finds in Njals sagas. ${ }^{51}$

In considering the David Saga as akin to Njals sagas Van Seters has focused on six major features of Njals sagas. The six features are as follows: (1) the focus is on the rivalries and feuds of founding families; (2) the sagas are based on earlier historical records; (3) the author stresses chronology, genealogy, place names, and memorial markers; (4) the story makes a judgement about the nation's past that has implications for the future; (5) the work complies with literary conventions and (6) it is possible (but not always the case) that these sagas are parodies. ${ }^{52}$ It would appear that this set of features fits quite well with the $\mathrm{SN}$. Nevertheless, I suggest that the genre of satire is a better fit. Indeed, as already stated, in this work I argue in detail that the SN meets a received definition of satire and, therefore, should be regarded as satire.

Satire, of course, may include some Njals sagas, however, Njals sagas are not always satirical. ${ }^{53}$ Icelandic sagas also appear to have a geographical and historical specificity as opposed to the more universal genre of satire. Moreover,

\footnotetext{
50 Van Seters, The Biblical Saga of King David, 354-355.

51 Ibid., 48.

52 Ibid., 49 .

53 Ibid.
} 
by contrast with a work belonging to the genre of satire, a work belonging to the genre of Njals sagas would not necessarily have a pervasive sense of irony (as the SN does) and comply with the literary conventions of irony, rhetorical devices, distortions, grotesqueries etc. For these reasons, I suggest that the SN is more appropriately regarded as belonging to the genre of satire than that of Njals saga.

The second line of inquiry which led me to suspect that the $\mathrm{SN}$ is a work of satire is my own research into irony in the SN. ${ }^{54}$ This line of research was largely inspired by Harold Bloom's work, The Book ofJ. Bloom argues that the author, J, was a woman who lived or worked near King Rehoboam (Solomon's son). Most notably, Bloom argues that the author J was an ironist. Furthermore, he mentions that there is considerable "social irony" in the Second Book of Samuel that is not easily categorized and is best thought of as unique to $\mathrm{J}$ (but in the style which we have come to know through Kafka). ${ }^{55}$ Bloom's claim is supported by my own research which suggests that the $\mathrm{SN}$ has a pervasive sense of irony. However, I argue that the author of the $\mathrm{SN}$ is an ironist and a satirist, since irony is an essential element of satire. ${ }^{56}$ By contrast Bloom argues that "the book of J" does not conform to any genre, and is not a moral document. ${ }^{57} \mathrm{In}$ the following sections I discuss satire and the features of satire ${ }^{58}$ that are present in the SN. This process begins with a brief account of the history of satire.

\subsubsection{What Is Satire?}

1.2.1.1 History of Satire

The word satire is derived from the Latin word satura which has come to mean brimming with a variety of different things. Gilbert Highet likens the word

54 Ingram, "David Remains in Jerusalem and Absalom Flees to Geshur: An Ironic Interpretation," and "The Kindness of Irony: A Psychological Look at Irony in 2 Samuel 11."

55 Harold Bloom, The Book of J (New York: Vintage Books, 1991), 4-24.

56 See also, Thomas Jemielity, Satire and the Hebrew Prophets (Louisville, Kentucky: John Knox Press, 1992), 195. Jemielity is another scholar who interprets biblical texts satirically. However, he only touches upon the suggestion that the Davidic narratives contain satire. Jemielity suggests that the pervasiveness of shame in the Hebrew Bible is tantamount to the ridiculing aspect of satire (particularly as shame presents with judgements) (22-24). In reference to the Succession Narrative shame is found in the case of Ahithophel's suicide (2 Sam. 16:23-17:23) (32) and in the case of Nathan's judgement against David (2 Sam. 11:27-12:13) (38). Jemielity suggests that the latter case is an example of the Hebrew prophet as satirist (85). He also identifies dissimulation in the self-indicting parable in 2 Sam. 12:1-14 (194).

57 Ibid., 13 .

$5^{8}$ It is beyond the scope of this research project to give a full account of satire. Instead, this overview shares the points which are generally agreed upon by scholars, acknowledging that significant debate still exists in the scholarship of satire. 
satura to the metaphor of a stew, which is a single unit that is full of different elements. A stew is also rich and earthy as compared to a plate of fine dining, which is sophisticated yet sparse, indicating that satire is coarse and varied. ${ }^{59}$

As the word satire was a Roman invention, ${ }^{60}$ the earliest satirist is sometimes spoken of as Horace (65-8 вСЕ). However, satiric elements can be discerned much earlier ${ }^{61}$ in Aristophanes (446-386 в С ) Old Comedy in Greece, ${ }^{62}$ the maqama tradition in semitic Gadara, ${ }^{63}$ and as early as $\left(2025^{-1700 ~} \mathrm{BCE}\right)$ in Egypt with The Satire of the Trades. ${ }^{64}$ Robert Elliot even proposes that the origins of satire were found in ancient curses. "Even today ... we speak of satire as "venomous," "cutting," and "stinging,"... Our language preserves the memory of a once-powerful belief: Archilochus' [680-635 BCE] verses had demonic power and his satire killed." ${ }^{65}$ Elliot linked this belief in the power of words to kill, with a belief in magic. ${ }^{66}$ Of note to this research project is Elliot's suggestion that the understanding of 'satire' as deadly magic had transformed into emotional insult by the time of David. He writes that the Arabic hija (which Elliot calls satire) was a curse that tribal poets would hurl at each other before a battle. This he contends morphed into bragging, as is demonstrated in the preliminary banter between David and Goliath. ${ }^{67}$ Notwithstanding this, it is tempting to suggest that the words which were exchanged between David and Goliath were more than bragging. For instance, Goliath speaks of cursing David (1 Sam. 17:43) and David might be seen to evoke the power of the Lord of Hosts (1 Sam. 45-47). Either way, as Elliot mentions, whether this exchange

\footnotetext{
59 Highet, The Anatomy of Satire, 231.

60 Ibid., 24.

61 It is worth noting that a solid body of scholarship has argued that it is not anachronistic to apply the work 'satire' to biblical texts. The most conclusive article on this subject is: M. Perry, "Caution a Literary Text," Ha-Shifrut. 2/3 (1970), 6o8-663.

62 Theodore D. Kharpertian, "Thomas Pynchon and Postmodern Satire," in A Hand to Turn the Time: The Menippean Satires of Thomas Pynchon (London: Associated University Press, 1990), 25-27.

63 Moses Hadas, Ancilla to Classical Reading (New York: Columbia University Press, 1954). In the maqama, a performer uses prose and verse to infuse humour into a serious moral discourse. Menippus adopted this style he had learned in Gadara in what is now referred to as Menippean Satire.

64 Oudheden Van, Rijksmuseum. "The Satire of the Trades" (2025-1700 BCE), in Encyclopedia of Disability, ed. Gary L. Albrecht, vol. 4 (Thousand Oaks, CA: SAGE Publications, Inc., 2006).

65 Robert C. Elliot, The Power of Satire (New Jersey: Princeton University Press, 1972), 4.

66 Ibid., 6.

67 Ibid., 16.
} 
was seen to be a curse or hurtful invective, the commonality in both cases is the desire to harm the opposition, and to gain control over him or her. ${ }^{68}$

The fear that satires created is well-documented. For instance, S. D. Goitein writes; Muhammad ... is reported twice to have ordered the execution of such powerful female satirists, who were greatly dreaded by even such a powerful man as the head of the new Muslim State. This makes it clear why King Saul was so upset when the "dancing women" in their songs of triumph ascribed, or, as the Bible says, "gave" to David the slaying of ten thousands and to him only thousands, or why Barak refused to wage war against Sierra unless Deborah would accompany him. The biting satires of the woman judge, some of which were later included in the so-called song of Deborah (Judges 5) were a most effective means of activating the languid tribes. Prophetesses were consulted or dreaded, up to the very end of the Old-Israelite prophetism, if we may judge from the examples of Hulda, who was approached by King Josiah, and Noadya, who was obviously a great nuisance to Nehemiah, the Governor of Judea in Persian times, even though he was an energetic and rather ruthless man (Nehemiah 6:14) ${ }^{69}$

It appears that satiric forms were evident in different cultures (including the OT), throughout history. What is significant for this research is the identifying features of satire and the function of satire. An in-depth analysis of both of these aspects of satire will follow.

\subsubsection{Identifying Satire}

Satire presents in different forms. It may appear as a monologue, a parody of an existing work, a fictitious drama, ${ }^{70}$ a biography, ${ }^{71}$ or satire might present as history writing. ${ }^{72}$ It may be of any length, however, if it is long, it will (in most cases) be episodic. ${ }^{73}$ Thereby, a satire cannot be discerned purely by form, but must also be considered for content. Thus,

\footnotetext{
68 Ibid., 292.

69 S. D. Goitein, Jews and Arabs. Their Contacts Through the Ages (New York: Schocken Books, 1964), 30, as cited in, Robert Elliot, The Power of Satire.

70 Highet, The Anatomy of Satire, 14.

71 Ibid., 216.

72 Ibid., 213.

73 Ibid., 206.
} 
When we speak of a satirical novel or a satirical play we probably have in mind a work of art which contains a sharp kind of irony or ridicule or even denunciation ... in short, satire has to do with tone and spirit (perhaps also purpose), but hardly with form. ${ }^{74}$

Satire also has a discernible object of attack. ${ }^{75}$ The targeted object is usually a political figure. ${ }^{76}$ This prompts Highet to suggest that most satire is written of real people, and real-life situations, usually involving some kind of corruption which the satirist is railing against. ${ }^{77}$

Traditionally the targets of satire are presented in ways which are humiliating and debasing in order to strip them (metaphorically) of their social standing. Mathew Hogdart argues, "By using obscenity, the satirist can go even further, reducing man from nakedness to the condition of an animal, in which any claim to social or even divine distinction must appear even more ridiculous." ${ }^{78}$ Other elements which may be present in a satire include "fantastic events,"79 "distortions" (which commonly appear as exaggerations and understatements), ${ }^{80}$ ridicule and parody, and "rhetorical features," which show that a work has been artistically crafted. ${ }^{81} \mathrm{~A}$ satire might also use coarse, or obscene language, and revel in graphic and challenging descriptions of events. ${ }^{82}$ However, irony is the most important, and most heavily utilised element in satire. ${ }^{83}$ The constant use of irony sets up two different levels in a text; one that presents the situation as it appears to the object of the attack (namely, in a benign light), another that is pejoratively critical of the object of attack. This duality of levels represents the struggle between two different perspectives and these perspectives may be held by different factions within a society or, indeed, by different competing societies. ${ }^{84}$ So, irony is essential to satire since it both sets up the two levels and forces the audience to make a judgement between the contrasting values embodied in these two different levels. ${ }^{85}$

74 Elliot, The Power of Satire, 101.

75 Northrop Frye, Anatomy of Criticism. Four Essays (New Jersey: Princeton University Press, 1990), 224.

76 Matthew Hodgart, Satire (London: World University Library, 1969), 7.

77 Ibid., 16.

78 Hodgart, Satire, 3 o.

79 Marcus, From Balaam to Jonah. Anti-prophetic Satire in the Hebrew Bible, 10.

$80 \quad$ Ibid., 11.

81 Marcus, From Balaam to Jonah. Anti-prophetic Satire in the Hebrew Bible, 22.

82 Highet, The Anatomy of Satire, 18.

83 Hodgart, Satire, 30.

84 Frye, Anatomy of Criticism. Four Essays, 224.

85 Ibid., 256. 
The form of irony definitive of satire is verbal irony. Moreover, the irony in instances of verbal irony is always intended. Therefore, the irony is not merely the unintended result of some conjunction of action and circumstance as in the well-known case of the pick-pocket whose own pocket is picked as he picks the pocket of others. ${ }^{86}$ Furthermore, in satire it is necessary that there is evidence of a pervasive and pejoratively critical sense of verbal irony, ${ }^{87}$ or in Northrop Frye's words, "militant irony." 88 However, upon saying this it is necessary to note that the study of satire is as diverse and unsettled as the study of irony. I accept the standard view of satire elaborated above, whilst acknowledging the extensive debate on the subject.

\subsubsection{Function of Satire}

Highet discusses two types of satirist which he calls the optimist and the pessimist. The optimist, Highet claims, likes people and hopes to cure them of their vices. The optimist uses frank and obscene words, however, he/she does this in order to shock an audience into facing the truth and in order to protest against injustices. ${ }^{89}$ The pessimist on the other hand hates people, as he or she finds them to be incurably evil and foolish. The pessimist thereby, does not hope for the restoration of the world, but conversely hopes to destroy the world through his/her cruel words, and brutal sentences. ${ }^{90}$ Thankfully, most scholars are less familiar with the dark-hearted satirist, and suggest that the primary function of satire is reform.

The satirist is not taken in by the hero of the epic rather the satirist sees through the smokescreen. Instead, the satirist will deflate the (seemingly) heroic in favour of presenting a truer version of events. ${ }^{91}$ It might then be said that the optimistic satirist is an idealist at heart, who hopes that an ideal world will come about through his or her denunciation of vice, folly, and injustice. ${ }^{92}$ The satirist is thereby, reformer, ${ }^{93}$ teacher ${ }^{94}$ healer, ${ }^{95}$ and artist. $^{96}$

86 D. C. Muecke, The Compass of Irony, 119-122.

87 Marcus, From Balaam to Jonah. Anti-prophetic Satire in the Hebrew Bible, 13.

88 Frye, Anatomy of Criticism. Four Essays, 224.

89 Ibid., 19.

9o Ibid., 235 .

91 Hodgart, Satire, 30.

92 Highet, The Anatomy of Satire, 243. Dryden writes that; "The true end of satire, is the amendment of vices by correction," as cited in Highet, The Anatomy of Satire, 241.

93 Ibid., 27.

94 Highet, The Anatomy of Satire, 243.

95 Ibid., 236.

96 Hodgart, Satire, 20. 


\subsubsection{Summary}

An overview of satire appeared in section 1.2.1. I discussed the origins of satire and I pointed out that satire has a cutting and confrontational quality and is an ancient literary form found in different cultures. I argued that satire does not necessarily conform to a standard form. However, all satires have at least one object of ironic attack who is usually a political or religious figure. The object of attack is portrayed in a way that is humiliating in order to challenge his or her social position. I discussed the function of satire and claimed that satire is predominantly used in order to excite reform. I argued that the satirist hopes for a better world to emerge from the denunciation of injustices and other wrongdoing. I argued that the identifying features of satire are generally taken to be fantastic elements, distortions, ridicule, parody, rhetorical features and irony. Of all of these features, irony is the only feature that is essential to satire. However, the irony in satire must be pervasive and pejoratively critical. I claimed that the identification of the presence of pervasive critical irony, and the identification of some of the other features of satire in a narrative, along with an object of ironic attack, is sufficient to determine that the narrative in question is a satire. In this book I conclude that the features of satire are evident in the SN and that the SN is in fact a satire. Indeed, I make the first indepth scholarly exploration of verbal irony in the SN. This exploration has the potential to advance understanding of the SN by opening up a fresh perspective, namely, that of the $\mathrm{SN}$ as satire. 